\title{
Dietary amino acids in nutrition
}

\author{
Keywords: amino acid, nutrition, human, protein
}

\section{Dear editor}

I would like to write a letter about importance of dietary amino acids in human nutrition because amino acids are necessary for optimal growth and play an important role in many physiological functions. The deficit of dietary amino acid intake may lead to the malnutrition which results in deficiency of muscle development at an early age or of muscle loss in later age.

\section{Dietary amino acids}

Dietary proteins are necessary for optimal growth and physiological functions in the body. The recommended dietary protein intake is $0.66 \mathrm{~g} / \mathrm{kg}$ of body weight ${ }^{1}$ however the athletes have greater requirements which are in the range $1.2-1.7 \mathrm{~g} / \mathrm{kg}$ body weight. ${ }^{2}$ Since the proteins are built of amino acids, the dietary amino acids are more important than proteins. All of the indispensable amino acids are necessary for protein synthesis because the body is not able to synthetize them. Moreover, protein synthesis is limited by limiting amino acid; which is the most in the least amount. The content of other amino acids, exceeding the content of limiting amino acid, is not utilized for protein synthesis. ${ }^{3}$ Therefore the accurate amount of dietary amino acids is necessary.

To know the content of dietary amino acids which are digestible in digestive tract is necessary for the protein quality evaluation of foods. Therefore the foods and protein sources should be evaluated based on the digestible amino acid content-content of dietary amino acids which are absorbed through the small intestine. Only in 2013 Food and Agriculture Organization ${ }^{1}$ introduced the new system of protein quality evaluation in human nutrition based on digestible indispensable amino acids.

Reports about dietary amino acid requirements are scarce. For example in sports nutrition the most of the studies dealing only with the dietary branched chain amino acids. On the other hand, in 1985 Food and Agriculture Organization reported protein and amino acid requirements in human nutrition ${ }^{4}$ and in $2007^{5}$ and $2013^{1}$ the requirements were re evaluated. There are differences among 1985 and 2007 and 2013, however the requirements between 2007 and 2013 are minimal. These requirements, for adults, relate to the maintenance and do not deal with the muscle growth. There is no information about the dietary requirements of amino acids for elderly people or for human active within sports, which have increasing demand on dietary amino acids.

\section{Sources of amino acids}

Animal proteins are considered of higher quality than plant ones due to the better profile of amino acids. For an example wheat or rice protein are poor in lysine while pulses are poor in sulphur amino acids in comparison with animal proteins. ${ }^{6}$ However, the combination of more proteins with different spectrum of amino acids is a good way to supplement sufficient amount of amino acids into the body.
Volume 5 Issue 2 - 2016

\author{
Matej Brestenský,' Soňa Nitrayová,' Peter \\ Patráš,' Jozef Nitray² \\ 'Department of Nutrition, Research Institute of Animal \\ Production Nitra, National Agricultural and Food Center, \\ Slovakia \\ ${ }^{2}$ Institute of Nutrition and Health R\&D, Tekmar Slovakia Ltd., \\ Slovakia
}

Correspondence: Matej Brestenský, Department of Nutrition, Research Institute of Animal Production Nitra, National Agricultural and Food Center, Hlohovecká 2, 95।41, Lužianky, Slovakia,Tel +4216546182,Email m_brestensky@vuzv.sk

Received: October 27, 2016 | Published: November 09, 2016

Moreover, in practice there is too difficult to ensure the accurate dietary intake of amino acids, especially for people required the greater amino acid intake (athletes, elderly people), due to different content of amino acids in particular protein sources. The easiest way is dietary intake of high quality proteins which will provide essential amino acids in to the body in sufficient amount. Use the blends of different proteins is also good alternative to provide sufficient content of amino acids into the body, because the different proteins with different spectrum of amino acids complement each other and thus the amino acids are provided into the body. Thus, the amino acid which is deficient in one protein is supplemented from another protein in which is in sufficient amount.

\section{Acknowledgements}

This article was written during realization of the project "ZDRAVIE no. 26220220176" supported by the Operational Programme Research and Development funded from the European Regional Development Fund.

\section{Conflict of interest}

Author declares that there is no conflict of interest.

\section{References}

1. Dietary protein quality evaluation in human nutrition. Report of an FAO Expert Consultation. Food and Agriculture Organization of the United Nations, Rome; Food and Agricultural Organization. 2013. 66 p.

2. Tipton KD, Wolfe RR. Protein and amino acids for athletes. J Sports Sci. 2004;22(1):65-79.

3. Bender DA. The metabolism of "surplus" amino acids. Br J Nutr. 2012;108(Suppl 2):S113-S121. 
4. Food and Agricultural Organization/World Health Organization/UNU. Energy and protein requirements. Report of a Joint FAO/WHO/UNU Expert Consultation. Geneva: World Health Organization; 1985. 206 p.

5. Food and Agricultural Organization/World Health Organization/UNU. Protein and amino acid requirements for human nutrition. Report of a Joint FAO/WHO/UNU Expert consultation. Geneva: World Health Organization; 2007. 265 p.
6. Singh BK. Amino acids and nutritional quality of plant products. Amino Acids. 2002;22:215. 